\title{
Results of 50 Phacoemulsification Surgeries with Injectable Lens Implantation at Indus Medical College Hospital Tando Mohammad Khan
}

\author{
Nisar Ahmed Khan*, Aftab Ahmed Khan, Aisha Khan, Atiqa Khan and Jawaid Iqbal Memon \\ Indus Medical College Hospital Tando Mohammad khan, Pakistan
}

Submission: March 12, 2017; Published: April 17, 2017

*Corresponding author: Nisar Ahmed Khan, FCPS (Ophth), Assistant Professor, Indus Medical College Hospital Tando Mohammad khan, Pakistan, Tel: +92 300-3014168; Email: Nisargh2001@yahoo.com

\begin{abstract}
Purpose: To evaluate the results of phacoemulsification surgeries at department of ophthalmology at Indus Medical College Hospital Tando Mohammad Khan.

Material and Methods: This study in which only 50 eyes of 43 patients were included to treat by phaco emulsification was conducted from 1st January to 30th June 2016. 31 patients were male whereas 12 were female. 20 were right eyes, 16 were left while 7 patients were undergone bilateral phaco surgeries within 7 to 16 days.1 patient was in age group C, another 1 was in group D, 8 were in group E, 12 were in group $\mathrm{F}$ and remaining 21 were in group G. 21 were suffering from diabetes, 12 were hypertensive, 2 were with cardiac problems using pace maker and 2 was involved with HCV infection. Patients suffering from ocular diseases: open angle glaucoma 3, pseudoexfoliation 4, pigment dispersion syndrome 1, chroniciritis 2, cholestrosisbulbi 1, asteroid hyalosis 1, age related macular degeneration 2 Eyes were dilated with mydriacil/phenylephrine eye drops, local anesthesia as retrobulbar as well as facial block (von lint technique) were given using $2 \%$ xylocaine inj without adrenaline. $2.8 \mathrm{~mm}$ incision, capsulorexhsis with bent 27 gauge needle, followed by hydrodissection and in some hydrodelienation with small caliber irrigation cannula, copious $2 \%$ methylcellulose used to save endothelial cells as well as to maintain anterior chamber, all 4 steps of phaco followed with divide and conquer method and finally injectable intraocular lens implanted. Every operation ended with subconjunctival injection of dexamethasone $2 \mathrm{mg}$ plus gentamicin $20 \mathrm{mg}$.
\end{abstract}

Results: 37 eyes gained 20/20 visual acquity on first post-operative day, 3 eyes gained 20/40, 5 gained 20/60 which over a period of five days improved to 20/20 after using topical prednisolone $1 \mathrm{mg}$ along with moxifloxacin eye drops, 3 gained 20/80 corrected with glasses, 2 were having 20/100 because of macular diseases.

Conclusion: In our experience phacoemulsification is an excellent technique which saves time, gives early rehabilitation depending upon the patience, experience and skill of surgeons.

Keywords: Cataract; Phacoemulsification results

\section{Introduction}

The term cataract is defined as an opacification of crystalline lens, having different morphological types; subcapsular; anterior and posterioir, cortical, nuclear opacification [1]. Cataract further divided according to density: grade 1 to grade 4 . Cataract leads to decreased or blurring of vision.

Mostly senile [2] with other important causes like trauma, dibetes, myotonic dystrophy, atopic dermatitis, neurofibromatosis type 2, steroid induced, chronic iritis, high myopia, retinitis pigmentosa, gyrate atrophy, Stickler syndrome etc. [3].
With the passage of time lens increases in weight and thickness as new layers of cortical fibers are formed concentrically, the lens nucleus undergoes compression and hardening (nuclear sclerosis). Crystalline (lense proteins) are changed by chemical modifications and aggregation into highmolecular-weight proteins [4].

The only treatment for cataract is surgery either large incision ECCE or phacoemulsification, small incision early rehabilitation and with good visual outcome. The technique and results of cataract surgery have changed dramatically during the past three decades. In all over the world we have moved from 
intracapsular cataract extraction as the preferred technique to almost exclusively extracapsular techniques. Smaller incisions have become the standard, with phacoemulsification now being the method of choice for most of surgeons [5].

\section{Material and Methods}

This study in which only 50 eyes of 43 patients were included to treat by phaco emulsification with injectable intraocular lens implantations at Indus Medical College Hospital Tando Mohammad Khan from $1^{\text {st }}$ January to $30^{\text {th }}$ June, 2016. All eyes were dilated prior surgery with mydriacil, phenylephrine eye drops, local anesthesia given using retrobalbur and facial (von lint) with $2 \%$ lidocaine (xylocain injections). Phaco done with infinity (Alcon) machine under Taggaki microscope.

Table 1: Gender.

\begin{tabular}{|c|c|c|c|}
\hline S.No & Gender & No. of Patients & \% \\
\hline 1 & Male & 31 & 72.09 \\
\hline 2 & Female & 12 & 27.9 \\
\hline
\end{tabular}

Out of 43 patients 12 were females, 31 were males (Table 1 ), patients were divided into different age groups as: there was no patients in group A and B, group C and D have only one patient respectively, group $\mathrm{E}$ includes 8 , group $\mathrm{F}$ includes 12 and group G includes 21 (Table 2).

Table 2: Age Groups.

\begin{tabular}{|c|c|c|c|}
\hline Age Groups & Ages & No. of Patients & Percentage \% \\
\hline A & $0-10 \mathrm{yrs}$ & Nil & 0 \\
\hline B & $11-20 \mathrm{yrs}$ & Nil & 0 \\
\hline C & $21-30 \mathrm{yrs}$ & 1 & 2.32 \\
\hline D & $31-40 \mathrm{yrs}$ & 1 & 2.32 \\
\hline E & $41-50 \mathrm{yrs}$ & 8 & 18.6 \\
\hline F & $51-60 \mathrm{yrs}$ & 12 & 27.9 \\
\hline G & $61-70 \mathrm{yrs}$ & 21 & 48.83 \\
\hline
\end{tabular}

\section{Table 3: Laterality.}

\begin{tabular}{|c|c|c|c|}
\hline S. No. & Laterality & No. of Patients & $\%$ \\
\hline 1 & Right Eye & 20 & 46.51 \\
\hline 2 & Left Eye & 16 & 37.2 \\
\hline 3 & Both Eyes & 7 & 16.27 \\
\hline
\end{tabular}

Table 4: Systemic Diseases.

\begin{tabular}{|c|c|c|c|}
\hline S.NO & $\begin{array}{c}\text { Systemic } \\
\text { Diseases }\end{array}$ & No. of Patients & $\%$ \\
\hline 1 & Diabetes & 21 & 48.83 \\
\hline 2 & Hypertention & 12 & 27.9 \\
\hline 3 & $\begin{array}{c}\text { Cardiac } \\
\text { Problem Using } \\
\text { Pacemacker }\end{array}$ & 2 & 4.65 \\
\hline 4 & HCV & 2 & 4.65 \\
\hline
\end{tabular}

Out of 50 eyes 20 were right, 16 left and 7 were both eyes (Table 3). 37 (86.04\%) Patients Were suffering with systemic diseases like diabetes (48.83\%), hypertention (27.90\%), cardiac problem, using pacemaker (4.65\%), HCV (4.65\%) underwent surgery after having fitness from their physicians (Table 4) 14 (32.55\%). Patients were suffering from ocular diseases like Glaucoma (6.97\%), pseudoexfoliation (9.30\%), Pigment dispersion syndrome $(2.32 \%)$, old healed iritis with peripheral ant Synaechae (4.65\%), Cholesterosisbulbi $(2.32 \%)$, asteroid hylosis $(2.32 \%)$, Age related macular degeneration (4.65\%) (Table 5).

Table 5: Ocular Diseases.

\begin{tabular}{|c|c|c|c|}
\hline S.NO & Ocular Diseases & No. of Patients & $\%$ \\
\hline 1 & $\begin{array}{c}\text { Chronic Simple } \\
\text { Glaucoma }\end{array}$ & 3 & 6.97 \\
\hline 2 & Pseudoexfoliation & 4 & 9.3 \\
\hline 3 & $\begin{array}{c}\text { Pigment Dispersion } \\
\text { Syndrome }\end{array}$ & 1 & 2.32 \\
\hline 4 & Chronic Iritis & 2 & 4.65 \\
\hline 5 & Cholesterosis Bulbi & 1 & 2.32 \\
\hline 6 & Asteroid Hyalosis & 1 & 2.32 \\
\hline 7 & $\begin{array}{c}\text { Macular } \\
\text { Degeneration, AMD }\end{array}$ & 2 & 4.65 \\
\hline
\end{tabular}

After asceptic techniques, drapping and using 2 drops of $10 \%$ povidine solution instilled into eye, after 1 minute copious irrigation done, incision started with $2.8 \mathrm{~mm}$ phaco knife, capsulorexhsis done with 27 gauge bent needle, hydrodissection and in some hydrdileanation using small caliber irrigation cannula, copious use of $2 \%$ methylcellulose to save endothelium as well as to maintain anterior chamber. All 4 steps of phaco followed and finally injectable intraocular lens implanted. Wound closed with stromal hydration. Every operation finished with sub conjunctival injection of Dexamethasone $2 \mathrm{mg}$ plus gentamicin $20 \mathrm{mg}$, and eye kept pached for 24 hours.

\section{Results}

50 eyes of 43 patients were undergone surgery by phacoemulsification with injectable intraocular lens implantation, 37 eyes (74\%) improved visual acuity to 20/20 at first postoperative day, 3 eyes (6\%) improved upto 20/40, 5 eyes (10\%) upto $20 / 60,3$ eyes (6\%) upto $20 / 80$, and 2 eyes (4\%) improved upto 20/100 (Table 6). Figure 1 a, b, c shows injectable lens implantation during one of our surgery.

Table 6: Visual out come.

\begin{tabular}{|c|c|c|c|}
\hline S.No & Visual Acuity & No. of Eyes & \% \\
\hline 1 & $20 / 20$ & 37 & 74 \\
\hline 2 & $20 / 40$ & 3 & 6 \\
\hline 3 & $20 / 60$ & 5 & 10 \\
\hline 4 & $20 / 80$ & 3 & 6 \\
\hline 5 & $20 / 100$ & 2 & 4 \\
\hline
\end{tabular}




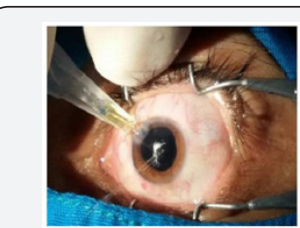

1 (a)

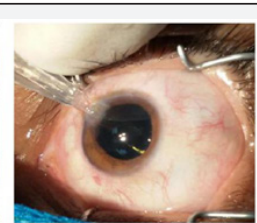

(b)

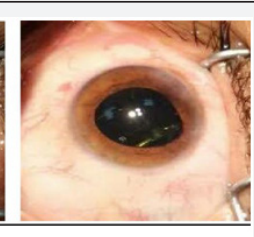

(c)
Figure 1: a,b,c Showing Foldable Intraocular Lens Implantation during one of our Surgery.

\section{Discussion}

Phacoemulsification is a very safe and less time taking technique depending upon good dilation of pupil pre- operative and during surgery as well as the patience, experience and skill of surgeons. It is established that the smaller phacoemulsification wound gives less induced astigmatism, faster visual rehabilitation and improved wound security than ECCE [6-11]. Smaller wound heals more rapidly with less risk of leakage, viscoelastic do not leave the eye through small incision [12]. 37 (74 \%) of my patient improved visual acuity upto 20/20 on first and secondday, 3 (6\%) developed striate keratitis and treated with topical steroid and regained $20 / 20$ on 5 th post operative day. In 5 (10\%) visual acuity corrected.

With glasses with in $-1.50 \mathrm{D}$ sphere and 0.75 cylinder at 90 degrees, $2(4 \%)$ who were suffering with age related macular degeneration remained after BCVA at 20/100. In our study not a single case suffered with post operative endophthalmitis same as in a study done by Cooper et al. [13].

Out of these 50 eyes only 3 developed striate keratitis, reason was hard nucleus more than grade 3 density needed high phaco power and time by the technique divide and conquer same as described by Gimbel [14]. Topical steroids were being prescribed and on 5 th postop day vision become $20 / 20$. Though it was fairly high $20 \%$ in one study by Popiela G et al. [15] but in our experience it was only $6 \%$, a grade 3 nucleus (severely dense) and long absolute phaco time as independent predictors for endothelial cell loss [16]. Phacoemulsification in the capsular bag by directing probe away from the corneal endothelium and keeping the lens fragments at deeper plane are the measures which would be helpful in minimizing the chances of corneal edema and striate after phacoemulsification same as suggested by Zetterstrin C [17] and Pirazzoli G et al. [18].

\section{Conclusion}

Small incision surgery such as phacoemulsification with injectable intraocular lens implantation is a very safe and less time taking technique which depends upon the experience and skill of surgeon who strictly follows selection and exclusion criteria and with a good knowledge when to abandon or convert the technique and always keeps the lens fragments in the capsular bag with the phaco tip directed away from endothelium, do not follow the lens fragments near the posterior capsule, allow fragments' to follow the tip.

\section{Acknowledgement}

I am thankful to Aftab Ahmed Khan assistant professor for his assistance, Aisha Khan (4th year MBBS) and Atiqa Khan (final year BDS) students for their help in compiling data. Special thanks to my assistant Moin Shaikh who assisted all cases. Jawaid Iqbal assistant professor who is always helpful.

\section{References}

1. kanski, Jack J (2011) Clinical ophthalmology; a systemic approach. 7: 270-271.

2. Brian G, Taylor H (2001) Cataract blindness-challenges for $21^{\text {st }}$ century. Bull world Health Organ 79(3): 249-256.

3. kanski, Jack J (2011) Clinical ophthalmology; a systemic approach. 7: 272-273.

4. American academy of ophthalmology (1998) Lens and cataract. American Academy of Ophthalmology, San Fransisco, California, USA.

5. Eric JL, David RH, Gaurav KS, Richard LL (1999) Phacoemulsification and Modern Cataract Surgery. Surv Ophthalmol 44(2): 123-147.

6. Watson A, Sunderraj P (1992) Comparision of small incision phacoemulsification with standard extra capsular cataract surgery: post-operative astigmatism and visual recovery. Eye 6(Pt 6): 626-629.

7. Werblin L, Sheridan PJ (1992) Astigmatism after cataract extraction: 6 years follow up of 6.5 and 12 millimeter incisions. Refract Corneal Surg 8(6): 448-458.

8. kanski, Jack J (2011) Clinical ophthalmology; a systemic approach. 7: 281.

9. Muralikrishan R, Venkatesh R, Babu B, Manohar P, Venkatesh N (2003) A comparision of the effectiveness and cost effectiveness of three different methods of cataract extraction in relation to the magnitude of post operative astigmatism. Asia Pacific J Ophthalmol 15: 5-12.

10. Demong TT, Yoshida K (1996) Evaluation of soft foldable IOLs in relation to PMMA lenses. Ophthalmic Practice 2: 61-64.

11. Khan AA, Azher AN, Chohan AM (1997) Review of 100 cases of phacoemulsification. Pak J Ophthalmol 13: 37-40.

12. Olson R (2004) Viscoelastic to the rescue. In: Obstbaum SA (Ed.), Moderator. Advances in cataract surgery: devices, application, techniques. Ophthamol Times 29(Suppl 3): 12-13.

13. Cooper BA, Holekamp NM, Bohigian G, Thompson PA (2003) Casecontrol study of endophthalmitis after cataract surgery comparing scleral tunnel and clear corneal wounds. Am J Ophthalmol 136(2): 300-305.

14. Gimbel HV (1991) Divide and Conquer Nucleofractis phacoemulsification: Development and variations. J cataract Refract Surg 17(3): 281-291.

15. Popiela G, Markuszewska J, Chelstowska J, Szaliński M (2004) Analysis of phacoemulsification complications during mastering of the method. Klin Oczna 106(1-2): 23-27.

16. O’Brien PD, Fitzpatrick P, Kilmartin DJ, Beatty S (2004) Risk factors for endothelial cell loss after phacoemulsification surgery by a junior resident. J Cataract Refract Surg 30(4): 839-843.

17. Zetterstrin C, Laurell CG (1995) Comparison of endothelial cell loss and phacoemulsification energery during endocapsulr phacoemulsification surgery. J Cataract Refract Surgery 21(1): 55-58.

18. Pirazzoli G, D' Eliseo D, Ziosi M, Acciarri R (1996) Effects of phacoemulsification time on the corneal endothelium using phacofracture and phaco chop techniques. J Cataract Refract Surg 22(7): 967-969. 
This work is licensed under Creative Commons Attribution 4.0 Licens

DOI:_10.19080/JOJO.2017.02.555597
Your next submission with Juniper Publishers will reach you the below assets

- Quality Editorial service

- Swift Peer Review

- Reprints availability

- E-prints Service

- Manuscript Podcast for convenient understanding

- Global attainment for your research

- Manuscript accessibility in different formats ( Pdf, E-pub, Full Text, Audio)

- Unceasing customer service

Track the below URL for one-step submission https://juniperpublishers.com/online-submission.php 